\title{
A questionnaire based study to assess the knowledge, attitude and practice (KAP) of rationale use of antibiotics among undergraduate dental students in a tertiary care dental hospital of South India
}

\author{
Tajuddin Shaik ${ }^{1}$, Bikash Ranjan Meher $^{2 *}$
}

\begin{abstract}
${ }^{1}$ Department of Pharmacology, Dilla Referral Hospital, Dilla University, Ethiopia ${ }^{2}$ Department of Pharmacology, All India Institute of Medical Science, Bhubaneswar, Odisha, India
\end{abstract}

Received: 20 November 2016 Accepted: 09 December 2016

\section{*Correspondence to:}

Dr. Bikash Ranjan Meher, Email:

bikash1meher@gmail.com

Copyright: () the author(s), publisher and licensee Medip Academy. This is an openaccess article distributed under the terms of the Creative Commons Attribution NonCommercial License, which permits unrestricted noncommercial use, distribution, and reproduction in any medium, provided the original work is properly cited.

\begin{abstract}
Background: To assess the knowledge, attitude and practice of rational use of antibiotics among dental students and make necessary interventions suitable to meet their need and aspiration.

Methods: Questionnaire was administered to the students of a dental college hospital to assess their knowledge, attitude and practice about rational use of antibiotics. Data was analysed after entering in to a Microsoft excel sheet and by using descriptive statistics.

Results: The response rate of our study was 100\%. Large majority (94\%) of the students knew that antibiotics were useful in bacterial infections. More than half of the students $(63.7 \%)$ believed that antibiotic resistance is a threat to mankind. A very less percentage $(23.3 \%)$ of students had ever attended (Continuous Medical Education) CME regarding the rational use of antibiotics.

Conclusions: This study showed that that most of the students possessed average knowledge about antibiotics. Their attitude was also not satisfactory towards rational use of antibiotics and same was true for the practice as well. Educational intervention is utmost essential to improve their KAP regarding rational use of antibiotics.
\end{abstract}

Keywords: Antibiotic, Dental, Rational, Under graduate

\section{INTRODUCTION}

Antibiotic resistance is a worldwide problem and menacingly spreading its tentacles day by day. ${ }^{1}$ It has reached an alarming proportion in developing countries because of various reasons like indiscriminate use of antibiotics and its availability as over the counter (OTC) drugs. ${ }^{2,3}$ Various studies suggested that, up to $50 \%$ of antibiotic use is deemed unnecessary. ${ }^{4}$ To increase the awareness about antibiotics uses, its advantages and pitfalls and to combat its resistance; various agencies are working in tandem. World Health Organization (WHO) is coming with different themes at time to time, like no action today, no cure tomorrow in 2011 or antibiotics, handle with care, in 2015 to increase awareness about rational antibiotic uses among common masses. Antibiotics play a pivotal role in dental practice for both prophylactic and therapeutic purposes. ${ }^{5}$ Multiple studies carried out across the world showed that antibiotics are not used prudently for various dental infections and it has lead to multiple complications including development of resistance. ${ }^{6}$ It is high time to create awareness, find and bridge the gap about different dimensions of antibiotic uses including antimicrobial stewardship and inculcate a practice of rational uses of drugs in general and antibiotics in particulars among budding medical and dental practitioners who will be the torchbearers of tomorrow. ${ }^{7,8}$ There are large number of studies to assess 
the KAP of medical students on antibiotic resistance as well as stewardship but few studies are there to measure the same in dental students. ${ }^{9-12}$ Keeping all these in mind this study was initiated to assess the KAP of rational antibiotic use among undergraduate dental students in a dental college hospital.

\section{METHODS}

\section{Study site}

A tertiary care teaching dental hospital of Chennai

\section{Study design}

Cross sectional, observational, questionnaire based study

\section{Study tool}

A structured questionnaires consisting of two parts. First part contains a set of questions for collection demographic data of participants and second part contains a set of questions to assess knowledge, attitude and practice of participants about rational use of antibiotics. It was developed by an expert group following related and relevant literatures.

\section{Study population}

Undergraduate dental students (Third year and Second year) who were voluntarily willing to participate in the study.

This study was a questionnaires based study. A structured questionnaire was designed by a team of experts. Questionnaire was validated among 20 dental students. Modified questionnaire was distributed to the participants after obtaining their informed consent and taking permission from dean of the institution. Participation was entirely voluntary and neither they were forced nor coerced at any level. Objectives of the study was explained to them and then asked to fill up the questionnaire in stipulated time of twenty minutes. Only completely filled questionnaires were included in the study for final analysis. Identity of the participants was kept confidential.

\section{Ethical consideration}

Study was commenced after obtaining permission from institutional ethics committee and scientific research committee.

\section{Statistical analysis}

All the data was entered in Microsoft excel sheet and statistical analysis was done by applying descriptive statistics.

\section{RESULTS}

A total number of 124 students participated in our study. All of them returned the completely filled questionnaire; response rate of our study was $100 \%$. Out of total number of participants, $64(52 \%)$ were from second year $(\mathrm{Gr}-1)$ and $60(48 \%)$ students were from third year (Gr-2). Out of 124 participants, $25(20 \%)$ were male and $99(80 \%)$ were female. Mean age of the participants was $17.66 \pm 0.77 \mathrm{yr}$ and $18.5 \pm 0.5 \mathrm{yr}$ for $2^{\text {nd }}$ year and $3^{\text {rd }} \mathrm{yr}$ year respectively. All demographic data are shown in Table 1.

Table 1: Demographic data.

\begin{tabular}{|c|c|c|}
\hline Students & $2^{\text {nd }}$ year & $3^{\text {rd }}$ year \\
\hline $\begin{array}{l}\text { Number of } \\
\text { participants }\end{array}$ & 64 & 60 \\
\hline Gender ratio & $\begin{array}{l}\text { Male-13 }(20.3 \%) \\
\text { Female-51 } \\
(79.7 \%)\end{array}$ & $\begin{array}{l}\text { Male-14 } \\
(23.3 \%) \\
\text { Females- } 46 \\
(76.7 \%)\end{array}$ \\
\hline Mean Age (yr) & $17.66 \pm 0.77$ & $18.5 \pm 0.5$ \\
\hline
\end{tabular}

Table 2: Knowledge about antibiotics.

\begin{tabular}{|c|c|c|c|c|c|}
\hline Sr. No & Questions & & Yes (Percentage) & No (Percentage) & P value \\
\hline \multirow{2}{*}{1} & \multirow{2}{*}{$\begin{array}{l}\text { Antibiotics are useful in bacterial } \\
\text { infections. }\end{array}$} & $2^{\text {nd }} \mathrm{yr}$ & $60(93.75)$ & $04(6.35)$ & \multirow{2}{*}{0.655} \\
\hline & & $3^{\text {rd }} \mathrm{yr}$ & $55(91.66)$ & $05(8.33)$ & \\
\hline \multirow{2}{*}{2} & \multirow{2}{*}{$\begin{array}{l}\text { Improper use of antibiotics can cause } \\
\text { antibiotic resistance }\end{array}$} & $2^{\text {nd }} y r$ & $51(79.68)$ & $13(20.31)$ & \multirow{2}{*}{0.148} \\
\hline & & $3^{\text {rd }} \mathrm{yr}$ & $41(68.33)$ & $19(31.66)$ & \\
\hline \multirow{2}{*}{3} & \multirow{2}{*}{$\begin{array}{l}\text { Super-infection is an adverse effect of } \\
\text { antibiotic uses }\end{array}$} & $2^{\text {nd }} y r$ & $12(18.75)$ & $52(81.25)$ & \multirow{2}{*}{$0.025^{*}$} \\
\hline & & $3^{\text {rd }} \mathrm{yr}$ & $22(16.66)$ & $38(83.33)$ & \\
\hline \multirow{2}{*}{4} & \multirow{2}{*}{ Ceftriaxone is a beta lactam antibiotic } & $2^{\text {nd }} y r$ & $21(32.81)$ & $43(67.18)$ & \multirow{2}{*}{0.241} \\
\hline & & $3^{\text {rd }} \mathrm{yr}$ & $14(23.33)$ & $46(76.66)$ & \\
\hline \multirow{2}{*}{5} & \multirow{2}{*}{$\begin{array}{l}\text { Antibiotic resistance is prompted by } \\
\text { self prescription }\end{array}$} & $2^{\text {nd }} y r$ & $51(79.68$ & $13(20.31)$ & \multirow{2}{*}{0.532} \\
\hline & & $3^{\text {rd }} \mathrm{yr}$ & $45(75.00)$ & 15 & \\
\hline \multirow{2}{*}{6} & \multirow{2}{*}{$\begin{array}{l}\text { Viral infection with fever should be } \\
\text { treated with antibiotics }\end{array}$} & $2^{\text {nd }} y r$ & $09(14.06)$ & $55(85.93)$ & 0.184 \\
\hline & & $3^{\mathrm{rd}} \mathrm{yr}$ & $14(23.33)$ & $46(76.00)$ & \\
\hline
\end{tabular}


In knowledge based question, maximum correct response was given for question no. 1 by both $2^{\text {nd }} \mathrm{yr}$ and $3^{\text {rd }} \mathrm{yr}$ students (93.75\% and $91.66 \%$ respectively) whereas least correct response was for question no. 6 by $(14.06 \%) 2^{\text {nd }}$ year students and for question no. 3 by $(16.66 \%) 3^{\text {rd }} \mathrm{yr}$ students. There is no statistically significant difference between two groups for knowledge based questions except question no. $2(\mathrm{p}<0.5)$. All data regarding participant's knowledge towards rational antibiotic uses are depicted in Table $2.58(90.6 \%) 2^{\text {nd }}$ year students and $44(73.33 \%) 3^{\text {rd }}$ year students think that self-medication is a contributing factor for emergence of antibiotic resistance and difference between two group is statistically significant $(\mathrm{p}<0.5)$. All data regarding participant's attitude towards rational antibiotic uses are depicted in Table 3.

Table 3: Attitude towards antibiotics.

\begin{tabular}{|c|c|c|c|c|c|}
\hline Sr. No. & Questions & & Yes (Percentage) & No (Percentage) & P value \\
\hline \multirow{2}{*}{1} & \multirow{2}{*}{$\begin{array}{l}\text { Do you think self medication promote } \\
\text { antibiotics resistance? }\end{array}$} & $2^{\text {nd }} \mathrm{yr}$ & $58(90.6)$ & $06(9.37)$ & \multirow{2}{*}{$0.011 * *$} \\
\hline & & $3^{\mathrm{rd}} \mathrm{yr}$ & $44(73.33)$ & $16(26.66)$ & \\
\hline \multirow{2}{*}{2} & Do you think antibiotic resistance is a public & $2^{\text {nd }} \mathrm{yr}$ & $37(57.81$ & $17(26.56)$ & \multirow{2}{*}{0.158} \\
\hline & health problem and potential threat to mankind? & $3^{\text {rd }} \mathrm{yr}$ & $42(70.00)$ & $18(30.00$ & \\
\hline \multirow{2}{*}{3} & \multirow{2}{*}{$\begin{array}{l}\text { Do you agree antibiotics should be prescribed } \\
\text { for all type of dental infections? }\end{array}$} & $2^{\text {nd }} \mathrm{yr}$ & $15(23.43$ & $49(76.56)$ & \multirow{2}{*}{0.107} \\
\hline & & $3^{\text {rd }} \mathrm{yr}$ & $22(36.66)$ & $38(63.33)$ & \\
\hline \multirow{2}{*}{4} & \multirow{2}{*}{$\begin{array}{l}\text { Do you think more expensive the antibiotics, } \\
\text { more effective it will be? }\end{array}$} & $2^{\text {nd }} \mathrm{yr}$ & $22(34.37)$ & $42(65.62)$ & \multirow{2}{*}{0.3521} \\
\hline & & $3^{\mathrm{rd}} \mathrm{yr}$ & $16(26.66)$ & $44(73.33)$ & \\
\hline
\end{tabular}

Table 4: Practice of antibiotics.

\begin{tabular}{|c|c|c|c|c|c|}
\hline Sr. No & Questions & & Yes (Percentage) & No (Percentage) & P value \\
\hline \multirow{2}{*}{1} & \multirow{2}{*}{$\begin{array}{l}\text { Have you ever attended a CME about } \\
\text { rational use of antibiotics? }\end{array}$} & $2^{\text {nd }} \mathrm{yr}$ & $12(18.75)$ & $52(81.25)$ & \multirow{2}{*}{0.207} \\
\hline & & $3^{\text {rd }} \mathrm{yr}$ & $17(28.33)$ & $43(75.00)$ & \\
\hline \multirow{2}{*}{2} & \multirow{2}{*}{$\begin{array}{l}\text { Have you ever advised antibiotic use to } \\
\text { someone? }\end{array}$} & $2^{\text {nd }} \mathrm{yr}$ & $54(84.37)$ & $10(15.62)$ & \multirow{2}{*}{0.213} \\
\hline & & $3^{\text {rd }} \mathrm{yr}$ & $55(91.66)$ & $05(8.33)$ & \\
\hline \multirow{2}{*}{3} & \multirow{2}{*}{$\begin{array}{l}\text { Have you ever taken any antibiotic } \\
\text { without consulting physician? }\end{array}$} & $2^{\text {nd }} y r$ & $53(62.81)$ & $11(17.18)$ & \multirow{2}{*}{0.141} \\
\hline & & $3^{\text {rd }} \mathrm{yr}$ & $55(57.66)$ & $05(8.33)$ & \\
\hline
\end{tabular}

Only $12(18.75 \%)$ students of $2^{\text {nd }}$ year and $17(28.33 \%)$ students of $3^{\text {rd }}$ yr have ever attended a CME on antibiotic resistance. 54 and 55 students from second year and $3^{\text {rd }} \mathrm{yr}$ respectively have advised antibiotics to someone. 53 $(62.81 \%) 2^{\text {nd }} \mathrm{yr}$ students and $55(57.66) \% 3^{\text {rd }}$ yr year students said that they have taken antibiotics without consulting a physician. There is no statistically significant difference between two groups for practice based questions. All data regarding participant's practice towards rational antibiotic uses are depicted in Table 4.

\section{DISCUSSION}

Our study was done with the objectives of assessing knowledge, attitude and practice of dental students towards rational antibiotic use. In our study we find that knowledge regarding different aspects of antibiotics is satisfactory but not excellent among dental students, similar observation was made by Sharma et al. In this study more than $90 \%$ of students replied correctly to question whether antibiotics are useful in bacterial infections which corroborates with finding of some other study like Giacomo Scaioli et al. Different stake holders and health agencies are raising concern that antibiotic resistance is a global public health problem and potential threat to mankind and we need to fight out this menace urgently. This study of us revealed that $64 \%$ students subscribed to this view which is in accordance with the study done by Afzal khan et al, among under graduate medical students. Self medication holds key to development of antibiotic resistance. Large number of participants in our study had practiced self medication with antibiotics; that is akin to a study done by Shubha $\mathrm{R}$ et al. Study done by Zafar SN, et al in medical students also demonstrated an increase incidence of self medication. Our study showed that attitude towards rational use of antibiotic is mixed; in one hand they think self medication promotes antibiotic resistance in other hand they think it can be prescribed for all types of infection irrespective of etiology. Same kind of lax attitude was seen in other study as well. ${ }^{13-15}$ Majority of our participants had advised their friends and relatives to take antibiotics for which they are not qualified and not supposed to .There should be a mandated guide line that who should prescribe antibiotics and who shouldn't and it should be enforced strictly at the national level. 


\section{CONCLUSION}

Sensitization and awareness need to be done through educational interventions. CMEs, and workshops need to be conducted at regular intervals to highlight the causes and impact antibiotic resistance. They also should be taught the ways and means to combat this menace. Curriculum also should be modified accordingly and different aspects of antibiotic resistance should be incorporated in their pharmacology course.

Funding: No funding sources

Conflict of interest: None declared

Ethical approval: The study was approved by the Institutional Ethics Committee

\section{REFERENCES}

1. WHO. The Evolving Threat of Antimicrobial Resistance: Options for Action; 2012.

2. Vila J, Pal T. Update on antimicrobial resistance in low-income countries: Factors favoring the emergence of resistance. Open Infect Dis J 2010;4:38-54.

3. Varghese RT, Das R. Antimicrobial drug resistance in India, Possible causes. Asian Stud Med J 2010;1:151-54.

4. Shiva H, Azadeh N, Mehdi R. Irrational antibiotic prescribing: a local issue or global concern? Excli Journal. 2013;12:384-395.

5. Lambrecht JT. Antibiotic prophylaxis and therapy in dental surgery. Schweiz Monatsschr Zahnmed. 2004;114:601-13.

6. Jaunay T, Sambrook P, Goss A. Antibiotic prescribing practices by South Australian general dental practitioners. Aust Dent J. 2000;45:179-86.

7. Rodriguez-Núñez A, Cisneros-Cabello R, VelascoOrtega E, Llamas-Carreras JM, Tórres-Lagares D, Segura-Egea JJ. Antibiotic use by members of the Spanish Endodontic Society. J Endow 2009;35:1198s-203.

8. Cope AL, Wood F, Francis NA, Chestnutt IG. General dental practitioners' perceptions of antimicrobial use and resistance: A qualitative interview study. Br Dent J. 2014;217:E9.

9. Ohl CA, Luther VP. Health care provider education as a tool to enhance antibiotic stewardship practices. Infect Dis Clin North Am. 2014;28(2):177-93.

10. Mahajan M, Dudhgaonkar S, Deshmukh S. A Questionnaire based Survey on the Knowledge,
Attitude and Practices about Antimicrobial Resistance and Usage among the Second year MBBS Students of a Teaching tertiary care Hospital in Central India. IJPR. 2014;4(4):175-9.

11. Abbo LM, Cosgrove SE, Pottinger PS, Medical Students' Perceptions and Knowledge about Antimicrobial Stewardship: How Are We Educating Our Future Prescribers? Clinical infectious diseases; 2013.

12. Sharma K, Jain P, Sharma A. Knowledge, attitude and perception of medical and dental undergraduates about antimicrobial stewardship. Indian J Pharmacol. 2015;47:676-9.

13. Khan AKA, Banu G, KKR. Antibiotic Resistance and Usage-A Survey on the Knowledge, Attitude, Perceptions and Practices among the Medical Students of a Southern Indian Teaching Hospital. J Clin Diagn Res. 2013;7(8):1613-161.

14. Dyar OJ, Pulcini C, Howard P, Nathwani D. On behalf of ESGAP, (the ESCMID Study Group for Antibiotic Policies). European medical students: a first multicentre study of knowledge, attitudes and perceptions of antibiotic prescribing and antibiotic resistance. $\mathrm{J}$ Antimicrob Chemother. 2013;69(3):842-6.

15. Minen MT, Duquaine D, Marx MA, Weiss D. A survey of knowledge, attitudes, and beliefs of medical students concerning antimicrobial use and resistance. Microb Drug Resist. 2010;16(4):285-9.

16. Scaioli G, Gualano MR, Gili R, Masucci S, Bert F. Roberta Siliquin Antibiotic Use: A Cross-Sectional Survey Assessing the Knowledge, Attitudes and Practices amongst Students of a School of Medicine in Italy PLoS One. 2015;10(4):e0122476.

17. Zafar SN. Self-medication amongst university students of Karachi: Prevalence, knowledge and attitudes. JPMA. 2008;58:214-17.

18. Shubha R, Madhav K. Savkar, Manjunath GN. Self medications pattern among dentists with antibiotics. Journal of Evolution of Medical and Dental Sciences. 2013;2(46):9037-41.

Cite this article as: Shaik T, Meher BR. A questionnaire based study to assess the knowledge, attitude and practice (KAP) of rationale use of antibiotics among undergraduate dental students in a tertiary care dental hospital of South India. Int J Basic Clin Pharmacol 2017;6:312-5. 